PiJIES: Pedagogik Journal of Islamic Elementary School April 2018, Vol.1, No.1, hal. 47-56

ISSN(P): 2356-1483; ISSN(E): 2615-3904

C 2018 PGMI IAIN Palopo. http:// ejournal-iainpalopo.ac.id/ PiJIES

\title{
MENINGKATKAN KETERAMPILAN MENULIS KARANGAN SEDERHANA MELALUI PENGGUNAAN MEDIA GAMBAR SERI
}

\author{
Hasmira \\ Institut Agama Islam Negeri Palopo \\ Jl. Agatis Balandai Kota Palopo, 91914 \\ E-mail: mirahasmira222@gmail.com
}

\begin{abstract}
This research is to find out how to improve the skill of writing simple essay through the use of drawing media series in fourth grade students of Islamic Elementary School Datok Sulaiman Palopo City. Research using qualitative and quantitative approach with Classroom Action Research (CAR) which is designed through two cycles. Research subjects, students of Islamic Elementary School Datok Sulaiman class IV that number 24 students. Data collection techniques used, namely observation, documentation, and tests. The research data obtained were analyzed by using descriptive statistic formula (percentage) to express descriptively the research result. Furthermore, to discuss and explain the results of research that is quantitative descriptive then used techniques of data reduction analysis, data presentation, and conclusion. The results of the study found that in prasiklus stage, the average score of students' writing skill is 54.37 with $20 \%$ classical learning completeness. After implemented the learning by applying Media drawing series, in the first cycle, the average score of students' simple writing skill is 56.25 with 50\% complete classical learning. Furthermore, the cycle IIdengan average value of simple writing skill is 76.45 with $66 \%$ complete classical learning. Thus, the skill of writing a simple essay in the fourth grade of Islamic Elementary School Datok Sulaiman Palopo by applying the series image media conducted from the first cycle to the 2 show significant results. Thus, serial image media need to be referenced by teachers in activities.
\end{abstract}

Keywords: Writing simple essays, media, and series drawings

\begin{abstract}
Abstrak
Penelitian ini untuk mengetahui bagaimana meningkatkan keterampilan menulis karangan sederhana melalui penggunaan media gambar seri pada siswa kelas IV SD Islam Datok Sulaiman Kota palopo. Penelitian dengan menggunakan pendekatan kualitatif dan kuantitatif dengan jenis Penelitian Tindakan Kelas (PTK) yang didesain melalui dua siklus. Subjek penelitian, siswa-siswi Sekolah Dasar Islam Datok Sulaiman kelas IV yang jumlahnya 24 siswa. Teknik pengumpulan data yang digunakan, yaitu observasi, dokumentasi, dan tes. Data penelitian yang diperoleh dinalisis dengan menggunakan rumus statistik deskriptif (persentasi) untuk mengungkapkan secara deskriptif hasil penelitian. Selanjutnya, untuk membahas dan menjelaskan hasil penelitian yang bersifat kuantitatif deskriptif maka digunakan teknik analisis reduksi data, penyajian data, dan penarikan kesimpulan. Hasil penelitian ditemukan bahwa pada tahap prasiklus, dengan nilai rata-rata keterampilan mengarang siswa adalah 54,37 dengan ketuntasan belajar klasikal 20\%. Setelah dilaksanakan pembelajaran dengan menerapkan Media gambar seri, pada siklus I maka nilai rata-rata keterampilan menulis karangan sederhana siswa adalah 56,25 dengan ketuntasan belajar klasikal 50\%. Selanjutnya, pada siklus IIdengan nilai rata-rata keterampilan menulis karangan sederhana adalah 76,45 dengan ketuntasan belajar klasikal 66\%. Dengan demikian, keterampilan menulis karangan sederhana di kelas IV SD Islam Datok Sulaiman Palopo dengan menerapakan media gambar seri yang dilakukan mulai dari siklus pertama sampai ke-2
\end{abstract}




\section{8 | Hasmira}

menunjukkan hasil yang signifikan. Jadi, media gambar seri perlu dijadikan referensi oleh guru dalam kegiatan.

Kata Kunci,: Menulis Karangan sederhana, media, dan gambar seri.

\section{PENDAHULUAN}

Pembelajaran bahasa Indonesia pada siswa sekolah dasar yang paling mendasar adalah keterampilan menulis, karena hal tersebut merupakan dasar pelajaran bagi kelas selanjutnya. "Keterampilan menulis adalah kemampuan mengungkapkan gagasan, pendapat, dan perasaan kepada pihak lain dengan melalui bahasa tulis" (Dewi Mustikowati, dkk., 2016:40). Hal ini sejalan dengan pendapat Sukirman dan Edhy (2010:3) "menyatakan bahasa adalah bahasa merupakan suatu sistem simbol lisan (oral) yang arbitrer dan konvensional yang digunakan oleh sekelompok masyarakat untuk berkomunikasi dan berinteraksi antara sesamanya berdasarkan budaya mereka". Menurut Nida dalam Tarigan (1981:1) "belajar bahasa menekankan empat komponen keterampilan berbahasa, yaitu: (1) keterampilan menyimak (listening skills), (2) keterampilan berbicara(speaking skill), (3) keterampilan membaca(reading skill), dan (4) keterampilan menulis (writing skill)".

Menurut Imron (2009:2) "menulis merupakan sebuah kegiatan menuangkan pikiran, gagasan, dan perasaan seseorang yang diungkapkan dalam bahasa tulis". Menulis adalah suatu kegiatan mengungkapkan atau menyatakan pikiran dan perasaan dalam bentuk tulisan yang dapat dipahami oleh pembaca dan berfungsi sebagai alat komunikasi tidak langsung. Hal ini sejalan dengan pendapat Byrne (2014: 163) "menyatakan keterampilan menulis pada hakikatnya bukan sekedar kemampuan menulis simbol-simbol grafis sehingga berbentuk kata, dan kata-kata disusun menjadi kalimat menurut peraturan tertentu, melainkan keterampilan menulis adalah kemampuan menuangan buah pikiran dalam bahasa tulis melalui kalimatkalimat yang dirangkai secara utuh, lengkap, dan jelas sehingga buah pikiran tersebut dapat diomunikasian kepada pembaca dengan berhasil". Dalam kegiatan menulis, keseimbangan otak kiri (logika) dan otak kanan (emosional) harus dimaksimalkan. Otak kanan memegang peranan penting dalam menghasilkan ide-ide baru, motivasi dan semangat siswa dalam menulis (Rustan, 2017)

Beberapa tujuan pembelajaran keterampilan menulis berdasarkan tingkatnya yaitu : 1) Tingkat Pemula seperti, menyalin satuan-satuan bahasa yang sederhana, menulis satuan bahasa yang sederhana, menulis pernyataan dan pertanyaan yang sederhana, menulis paragraph pendek dan 2) Tingkat lanjutan seperti, menulis paragrap, menulis surat, menulis berbagai jenis

\section{PiJIES: Pedagogik Journal of Islamic Elementary School}


karangan dan menulis karangan (Iskandarwassid dan Dadang Sunendar 2008: 292). Oleh karena itu, guru akan memberikan tugas dalam mempelajari dasar-dasar menulis kepada siswa.

Menurut Wahyu Kurnianingsi (2012:xi) "karangan sederhana adalah mengorganisasikan ide atau gagasan secara tertulis dalam bentuk karangan sederhana yang terdidri atas beberapa kalimat". Seperti pendapat Alwi (2010:132) "menyatakan bahwa karangan merupakan rentetan kalimat yang berkaitan yang menghubungkan proposisi yang satu dengan proposisi yang lain sehingga membentuk kesatuan yang cerita, buah pena, ciptaan, gubahan, cerita mengada-ada, dan hasil rangkaian". Menurut Tarigan (2008:40) karangan pada hakikatnya adalah akumulasi dari beberapa paragraph yang tersusun secara sistematis, koheren, memiliki kesatuan, ada bagian utama pengantar, isi, dan penutup. Menurut Asnawir dan Basyiruddin (2002:11) "menyatakan bahwa media sebagai benda yang dapat dimanipulasikan, dilihat, didengar, dibaca atau dibicarakan beserta instrument yang dipergunakan dengan baik dalam kegiatan belajar mengajar". Seperti pendapat Wahyu kurnianingsi (2012:xi) "gambar seri adalah urutan gambar yang mengikuti suatu percakapan dalam hal memperkanalkan atau menyajikan arti yang terdapat pada gambar".

Hasil penelitian yang dilakukan peneliti bahwa 24 siswa yang menjadi sampel sekaligus ikut melakukan tes awal ternyata sebanyak 5 siswa (20\%) dapat diklasifikasikan baik, 7 siswa (29\%) diklasifikasikan cukup, 6 siswa (25\%) diklasifikasikan kurang dan 6 siswa (25\%) diklasifikasi gagal. Salah satu persoalan dalam dunia pendidikan saat ini adalah lemahnya kualitas pembelajaran yang dilakukan guru dikelas. Di dalam melakukan praktek pembelajaran seringkali menggunakan media yang tidak sesuai dengan karakteristik siswa sehingga kurang melibatkan siswa didalam proses pembelajaran sehingga pemahaman belajar siswa tidak sesuai dengan yang diharapkan.

Permasalahan ini harus diatasi agar kualitas pembelajaran yang dilakukan guru dapat meningkatkan pemahaman siswa yang pada akhirnya dapat meningkatkan keterampilan menulis karangan sederhana siswa. Salah satu media yang dapat digunakan guru adalah media gambar seri. Para siswa diberi kesempatan oleh guru untuk mempelajari struktur bahasa dengan menentukan tema, penggunaan tanda.

\section{METODE}

Penelitian tindakan kelas ini difokuskan pada aktivitas pembelajaran di dalam kelas. Peneliti menggunakan model penelitian tindakan kelas yang 


\section{0 | Hasmira}

diterapkan oleh Kurt Lewin. "Prosedur penelitian menggunakan langkah sebagai berikut (1) Perencanaan, (2) Pelaksanaan, (3) Observasi dan (4) Refleksi" (Wina Sanjaya, 2013:50). Dalam penelitian ini peneliti menggunakan jenis data untuk mendukung penelitiannya, diantaranya a) Data primer adalah data yang dikumpulkan peneliti sendiri dengan cara melakukan observasi dan wawancara dengan pihak sekolah khususnya guru kelas IV. b) Data sekunder adalah data yang dikumpulkan oleh orang lain dalam hal ini guru kelas IV berupa dokumen/arsip siswa. Hal ini sejalan dengan pendapat Edhy Rustan yaitu "pengumpulan data dilakukan melalui teknik dokumentasi, dengan menelaah beberapa referensi tentang penguaan bahasa, baik yang berupa buku, jurnal, majalah, koran, laporan hasil penelitian maupun dokumen-dokumen yang relevan dengan permasalahan yang diteliti". Teknik tes, observasi dan dokumentasi digunakan untuk mengumpulkan data penelitian ini.

Pengelolaan data pada penelitian ini dilakukan setelah terkumpulkannya data. Kemudian dianalisis secara kuantitatif digunakan analisis deskriptif yaitu skor rata-rata dan persentase. Sedangkan analisis kualitatif dilakukan terhadap data yang diperoleh melalui observasi aktivitas guru dan siswa dalam pelajaran Bahasa Indonesia dengan menggunakan media gambar seri dengan langkah 1) reduksi data, 2) penyajian data dan 3) penarikan kesimpulan. Suharsimi (2002:264) Analisis ini dihitung dengan menggunakan rumus statistik sederhana yaitu $M \mathrm{x}=\stackrel{\frac{\mathbb{Z}}{N}}{N}$ menjumlahkan semua nilai yang diperoleh siswa selanjutnya dibagi dengan jumlah siswa kelas yang mengikuti tes tersebut sehingga diperoleh nilai rata-rata, hasil penelitian yang telah diperoleh tersebut kemudian diklasifikasikan ke dalam bentuk penskoran nilai siswa dengan menggunakan kriteria standar penilaian. Anas Sudijono (2009: 43) rumus untuk mencari frekuensi $\mathrm{P}=\frac{\mathrm{f}}{\mathrm{N}} \times 100 \%$ bila target ketegori tuntas $80 \%-100 \%$ dan sebanyak $<20 \%$ berada dalam kategori tidak tuntas.

Analisis ini dihitung dengan menggunakan statistik sederhana menjumlahkan nilai yang diperoleh siswa selanjutnya dibagi dengan jumlah siswa kelas tersebut sehingga didapatkan nilai rata-rata, hasil penelitian yang telah didapatkan tersebut kemudian diklasifikasikan kedalam bentuk penskoran nilai siswa dengan menggunakan criteria standar penilaian. Bila target kategori tuntas hanya sebesar $80 \%$ dan sebanyak $20 \%$ berada dalam kategori tidak tuntas. Maka dilaksanakan siklus II. 


\section{HASIL PENELITIAN}

Indonesia terhadap siswa kelas IV SD Islam Datok Sulaiman Palopo Kecamatan Wara kota Palopo, dapat diketahui hasil belajar siswa dapat meningkat. Hal tersebut dapat diketahui berdasarkan hasil observasi yang dilakukan pada setiap pertemuan mulai dari prasiklus, siklus I, dan siklus II. Peningkatan digambarkan dalam diagram sebagai berikut.

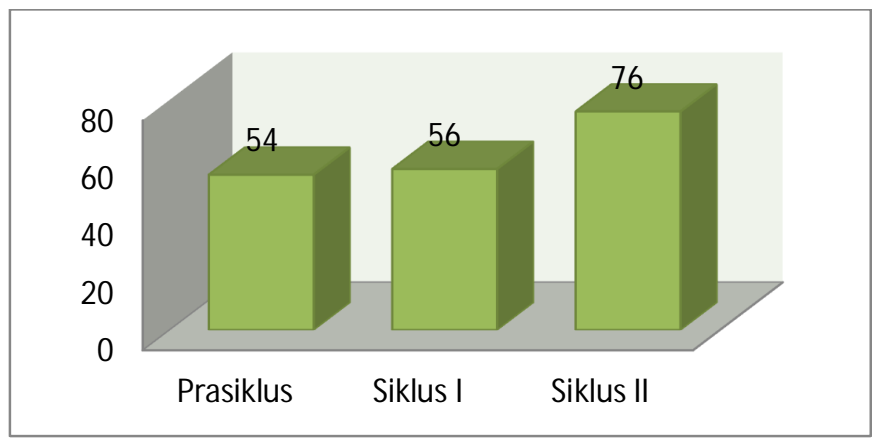

\section{Diagram Hasil Belajar Siswa}

Berdasarkan tes awal di prasiklus dapat diketahui bahwa dari 24 siswa yang menjadi sampel sekaligus ikut dalam melakukan tes awal ternyata 6 siswa yang mendapat nilai termasuk kategori gagal, 6 siswa yang mendapat nilai termasuk kategori kurang, 6 siswa yang mendapat nilai termasuk dalam kategori cukup 7, dan kategori baik 5 dan sangat baik tidak ada siswa yang mendapat nilai tersebut.

Berdasarkan diagram siklus I dan II tersebut menunjukkan peningkatan keterampilan menulis karangan sederhana pada siswa kelas IV SD Islam Datok Sulaiman Kota Palopo telah mengalami peningkatan dari tahap prasiklus nilai rata-rata siswa mencapai 59 dengan persentasi ketuntasan $54,37 \%$ dan pada tahap siklus I dan siklus II meningkat dengan nilai rata-rata mencapai 70 dan 85 dengan persentasi ketuntasan 94,73\%. Jadi, penerapan media gambar seri pada pembelajaran dapat meningkat keterampilan menulis karangan siswa.

\section{PEMBAHASAN}

Pembahasan pokok ini adalah upaya untuk meningkatkan pengetahuan siswa tentang materi pokok gambar seri seperti menyusun gambar seri dan membuat karangan sesuai urutan gambar seri.

Melalui penggunaan media gambar seri dalam upaya meningkatkan keterampilan menulis karangan sederhana siswa seperti menyusun gambar seri dan membuat karangan sesuai urutan gambar seri. Dengan melihat konsep (1) apa yang sudah diketahui (2) apa yang belum diketahui (3) apa 


\section{2 | Hasmira}

yang perlu atau yang seharusnya diketahui dengan cara menjelaskan materi yang disampaikan dan menuliskan karangan sederhana sesuai gambar seri. Hal tersebut sesuai dengan kajian teori yang dikemukakan oleh Bruns dkk., (1996:386) bahwa pembelajaran menulis mestinya dipusatkan pada siswa. Artinya siswa diberi kesempatan seluas-luasnya untuk mengembangkan kemampuan berpikir dan nalarnya secara baik guna melahirkan sikap kritis dan terampil dalam aktitas menulis. Sebelum sampai pada tahap menulis produktif, siswa terlebih dahulu mulai tingkat awal, tingkat permulaan, mulai dan pengetahuan lambing-lambang bunyi (Slamet, 2007:57).

Penerapan media gambar seri ini dapat ditampilkan dengan beberapa contoh gambar seri untuk dijelaskan, jika guru dapat menerapkan media ini dapat membantu meningkatkan keterampilan dan kreatifitas guru dalam mengajar karena media gambar seri ini mudah dipahami oleh siswa dan dapat meningkatkan keterampilan siswa dalam belajar dan media ini juga dapat bermanfaat bagi peneliti dalam menuangkan idenya sesuai dengan materi yang disampaikan. Selanjutnya, media ini juga dapat membantu guru untuk memberikan contoh secara langsung kepada siswa tentang gambar seri yang lebih jelas dan mudah dipahami. Media gambar seri ini adalah salah satu cara yang mudah dalam meningkatkan pengetahuan siswa dapat menarik keterampilan menulis karangan sederhana siswa dalam bekerja sama dalam kelompok masing-masing dan dapat lebih cepat dipahami.

Hasil penelitian membuktikan bahwa dengan menerapkan media gambar seri dalam meningkatkan keterampilan menulis karangan sederhana dengan materi seperti mengurutkan gambar seri dan membuat karangan sederhana sesuai urutan gambar seri. Hasil pra siklus menunjukkan bahwa keterampilan menulis karangan sederhana siswa dalam mempelajari bahasa Indonesia materi pokok yaitu menulis karangan sederhana sesuai dengan gambar seri sangatlah rendah. Hal ini yang mendorong peneliti untuk mendapatkan sumber data. Pemilihan media ini tidak menyulitkan guru dalam memberikan media ini karena sangatlah mudah untuk dikerjakan dan menyampaikan materi melalui media gambar seri sangatlah mudah dan membantu proses pembelajaran.

Hasil penelitian menunjukkan bahwa dengan menerapkan media gambar seri dalam meningkatkan keterampilan menulis karangan sederhana dengan materi menulis karangan sederhana. Hal ini menunjukkan bahwa pengguaa media gambar seri merupakan salah satu media yang sangat baik dalam meningkatkan keterampilan meulis karagan sederhana siswa terhadap mata pelajaran Bahasa Indonesia, dengan materi menulis karangan. Selain itu, peningkatan juga terjadi karena adanya motivasi yang guru berikan kepada siswa, siswa merasa terangsang serta terdorong untuk 
melakukan kegiatan yang berhubungan dengan pembelajaran yang sedang berlangsung sehingga nilai rata-rata yang siswa dapatkan meningkat atau mengalami perubahan. Hal ini sejalan dengan pendapat David McClelland, yang dikutip oleh Hamzah B Uno yaitu motif merupakan implikasi dari hasil pertimbangan yang telah dipelajari (redintegration) dengan ditandai suatu perubahan pada situasi afektif. Sumber utama munculnya motif adalah dari rangsangan (stimulasi) perubahan situasi sekarang dengan situasi yang diharapkan, sehingga tanda perubahan tersebut tampak pada adanya perbedaan afektif saat munculnya motif dan saat usaha pencapaian diharapkan. Di sisi lain, untuk menggerakkan motivasi dan meningkatkan kemampuan kognitif, siswa hendaknya memiliki efikasi diri yang positif dimana siswa memiliki keyakinan akan kemampuan yang dimilikinya (Thaha \& Rustan, 2017). Hal ini menunjukkan bahwa penggunaan media merupakan salah satu media yang sangat baik diterapkan dalam meningkatkan keterampilan menulis siswa terhadap mata pelajaran Bahasa Indonesia.

Evaluasi peningkatan kemampuan menulis karangan sederhana materi menulis karangan sederhana dengan mengurutkan sesuai dengan gambar, setelah dilakukan tindakan pertama dan kedua menunjukkan hasil yang cukup menggembirakan karena dapat meningkatkan keterampilan menulis karangan sederhana. Hasil tes pra siklus menunjukkan bahwa keterampilan menulis karangan sederhana sangat rendah. Untuk kategori sangat baik 0 , kategori baik 12 siswa, kategori cukup 7 siswa, kategori kurang 5 siswa, kategori gagal 0.

Hasil tes siklus pertama menunjukkan bahwa pengetahuan siswa tentang materi menulis karangan sederhana. Pada siklus pertama ini masih tergolong sangat rendah terdapat 5 siswa yang belum mencapai KKM yang ditentukan.

Hasil tes siklus kedua telah menunjukkan peningkatan keterampilan menulis karangan sederhana pada siswa selama diterapkan media gambar seri dengan penerapan pembelajaran ini telah mengalami peningkatan setelah melihat hasil tes dan praktek siswa dari siklus pertama masih terdapat 5 siswa yang keterampilan menulis karangannya masih sangat kurang, pada siklus kedua keterampilan menulis karangan sederhana pada siswa semua sudah meningkat.

\section{PENUTUP}

Berdasarkan hasil penelitian yang diperoleh dan dianalisis maka dapat disimpulkan bahwa penggunaan media gambar seri dapat meningkatkan keterampilan menulis karangan sederhana siswa. Hal itu terlihat dari 


\section{4 | Hasmira}

antusias siswa dalam proses pembelajaran dan hasil membuat karangan disetiap siklusnya meningkat. Kegiatan belajar siswa lebih komunikatif dan menyenangkan. Dalam pembelajaran menulis karangan sederhana sebelum menggunakan media gambar seri siswa terlihat pasif, kurang termotivasi, dan menganggap menulis itu menjenuhkan. Dengan penggunaan media gambar seri dalam proses pembelajaran siswa menjadi lebih aktif, dapat menuangkan gagasannya dengan baik. Penggunaan media gambar seri dapat meningkatkan keterampilan menulis karangan sederhana pada siswa kelas Iv sd Islam Datok sulaiman Kota palopo.

\section{DAFTAR PUSTAKA}

Asnawir dan Basyiruddin Usman, 2002. Media Pembelajaran. Cet. I: Jakarta: Ciputat Pers.

Arikunto, Suharsimi, 2002. Dasar-dasar Evaluasi Pendidikan. (Ed.Revisi III; Jakarta: Bumi Aksara).

Bahri, Syaiful Djamarah \& Aswan Zain, 2010. Strategi Belajar Mengajar. (cet,4; Jakarta: Rineka Cipta).

Burns, Paul C.,Roe B., \& Ross, E.P, 1996. Tecahing Reading in Today's Elementary School, Oston Hougthon Company.

Hidayah, Wahni, 2016, Peningkatan Keterampilan Menulis Permulaan Menggunakan Buku Harian Siswa Kelas I A SDN Plebengan Sidomulyo Bantul Tahun 2015/2016, Yogyakarta, skripsi Program Studi Pendidikan Guru Sekolah Dasar Jurusan Pendidikan Sekolah Dasar Fakultas Ilmu Pendidikan Universitas Negeri Yogyakarta.

Iskandar wassid dan Dadang Sunendar, 2008. Strategi Pembelajaran Bahasa, Bandung: Remaja Rosdakarya.

Kundharu Saddhono dan Slamet, 2014. Cet. I: Pembelajaran Keterampilan Berbahasa Indonesia. Yogyakarta Graha ilmu.

Rustan Edhy, 2016, Analisis Penggunaan Bahasa Indonesia Laras Hukum Pada Putusan Perkara Ekonomi Syariah Pengadilan Agama Makassar, (Makassar: Jurnal Of Islamic Ecoomic Law, 2016)

Rustan, E. (2017). Learning Creative Writing Model Based on Neurolinguistic Programming. International Journal of Language Education and Culture Review, 3(2), 13-29. https:/ / doi.org/ 10.21009/ IJLECR.032.02

Rosidi Imron,2009. Menulis Siapa Takut, yogyakarta:kanisius.

Sanjaya, Wina, 2013. Penelitian Tindakan Kelas, Jakarta: Kencana Prenadamedia Group. 
Sudijono Anas, 2007. Pengantar Statistik Pendidikan. Ed. Ke-I; Jakarta: Raja Grafindo Persada.

Sudijono, Anas, 2016. Pengantar Evaluasi Pendidikan. Cet. VI; Jakarta: Raja Grafindo Persada.

Susanto, Ahmad, 2014. Teori Belajar dan Pembelajaran di Sekolah Dasar. Cet. III; Jakarta: Kencana Prenada Media.

Sukirman Nurdjan, Edhy Rustan, 2010. Kunci Sukses Berbahasa Indonesia, Stain Palopo.

Sudijono, Anas, 2009. Pengantar Evaluasi Pendidikan. Jakarta: PT Rajagrafindo Persada.

Slamet, Y, 2007, Dasar-dasar Pembelajaran Bahasa dan Sastra di Sekolah Dasar. Surakarta: UNS Press.

Thaha, H., \& Rustan, E. (2017). Orientasi Religiusitas dan Efikasi Diri dalam Hubungannya dengan Kebermaknaan Pendidikan Agama Islam pada Mahasiswa IAIN Palopo. Studi Agama Dan Masyarakat, 13(2), 163-179. https:// doi.org/ 10.23971/ jsam.v13i2.551

Tarigan, Henry Guntur. Membaca Sebagai Suatu Keterampilan Berbahasa. Bandung: FKSS IKIP. 1981.

Wassid, Iskkandar, 2008. Strategi Pembelajaran Bahasa. Bandung: Remaja Rosdakarya.

Wahyu Kurnianingsi, Penggunaan Media Gambar Seri Untuk Meningkatkan Kemampuan Menulis Karangan Sederhana Kelas II SDN I Balingasal, (Surakarta: Jurnal Fakultas Keguruan dan Ilmu Pendidikan Universitas Sebelas Maret Surakarta, 2012) 
56 | Hasmira

Halaman ini sengaja dikosongkan

$-X X X-$

PiJIES: Pedagogik Journal of Islamic Elementary School 